\title{
Comparison of the expression of interferon $\gamma$, IL2, IL4, and lymphotoxin mRNA in experimental autoimmune uveoretinitis
}

\author{
David G Charteris, Susan L Lightman
}

\begin{abstract}
The aim of this study was to investigate the $T$ lymphocyte subsets involved in experimental autoimmune uveoretinitis (EAU) by quantifying the numbers of cells expressing mRNA for each of the lymphokines interferon $\gamma$, interleukin 2, interleukin 4, and lymphotoxin throughout the disease process. Lewis rats were immunised with retinal S-antigen to provide a model of inflammatory eye disease. In situ hybridisation using CDNA probes specific for interferon $\gamma$, IL2, IL4, and lymphotoxin mRNA were utilised to localise lymphokine mRNA expression by infiltrating cells and the numbers of positive cells counted. Localisation of mRNA for all four probes was found on increasing cell numbers as the disease process progressed. Similar numbers of cells expressed mRNA for each lymphokine, generally a small percentage of the $\mathbf{T}$ lymphocyte total. Activated cells within the eye express mRNA for interferon $\gamma$, IL2, IL4, and lymphotoxin in EAU suggesting a mixed population of $T$ lymphocyte subsets.
\end{abstract}

(Br f Ophthalmol 1994; 78: 786-790)

Studies of the intraocular immunopathology seen in chronic immune mediated ocular inflammatory disease have shown that the predominant infiltrating cell type is the CD4+ $\mathrm{T}$ lymphocyte. ${ }^{1-5}$ The destructive cellular infiltrate found in the posterior segment of human eyes is analogous to that found in experimental autoimmune uveoretinitis (EAU), an animal model of immune mediated ocular inflammation. ${ }^{6}$ In the Lewis rat model of EAU, immunisation is followed 10 to 12 days later by a mixed infiltrate of polymorphonuclear leucocytes and lymphocytes to the anterior and posterior segments, with CD4+ $\mathrm{T}$ cells predominating in the destructive retinal lesions. ' A role for CD4+ T cells in the initiation of EAU has been supported by the finding that these cells can adoptively transfer disease. ${ }^{8}$

The function of CD4+ T lymphocytes has

Correspondence to: Mr D G Charteris, Moorfields Eye Hospital, City Road, London ECIV 2PD.

Accepted for publication 15 June 1994 (IL2), interferon $\gamma$ (IFN- $\gamma$ ), and lymphoto thought to provide a cytotoxic effector cell role whereas interleukin 4 (IL4) production has been associated with a helper cell function.
We have previously investigated the in vivo production of the lymphokines IL2, IFN- $\gamma$, IL4, and lymphotoxin in the Lewis rat model of EAU ${ }^{11} 12$ by in situ hybridisation analysis of the expression of lymphokine mRNA in the areas of $\mathrm{T}$ cell infiltration and tissue destruction. These studies have shown that all four lymphokines are produced in destructive foci in the retina and uveal tract, and that the cell numbers expressing the lymphokine mRNAs are found in areas of $\mathrm{T}$ lymphocyte infiltrate and appear to increase as the disease progresses. The aim of this study is to extend these investigations by quantifying the numbers of cells producing these lymphokines throughout the disease course to identify the potential $\mathrm{T}$ cells subsets involved and to provide information on the possible role of the infiltrating CD4+ T lymphocytes.

\section{Materials and methods}

The experimental methods used in these studies have been described in detail elsewhere. ${ }^{112}$ They are summarised as follows.

EAU MODEL

Female Lewis rats, weighing $100-150 \mathrm{~g}$ and 6-8 weeks old, were immunised in a hind footpad with $50 \mu \mathrm{g}$ of purified bovine S-antigen in a 1:1 emulsion in complete Freund's adjuvant supplemented with Mycobacterium tuberculosis organisms to a final concentration of $2.5 \mathrm{mg} / \mathrm{ml}$. Animals were also given $5 \times 10^{9}$ heat inactivated Bordetella pertussis organisms in $150 \mu \mathrm{l}$ phosphate buffered saline intraperitoneally. Eyes were rapidly removed, embedded in OCT (Shandon, Runcorn) and snap frozen in acetone and dry ice. Specimens were stored at $-70^{\circ} \mathrm{C}$.

\section{IN SITU HYBRIDISATION}

Four cDNA probes were used for the in situ hybridisation. The probe to rat IFN- $\gamma^{13}$ was supplied by Dr T Kos, Rijswijk, The Netherlands. The rat IL2 probe $^{14}$ and the rat IL4 probe ${ }^{10}$ were supplied by Dr A McKnight, MRC Cellular Immunology Unit, Oxford. The lymphotoxin probe ${ }^{15}$ was given by Dr N Ruddle, Yale University Medical School, New Haven, CT, USA. The cDNA probes were radiolabelled with ${ }^{35} \mathrm{~S}$ dCTP alpha (Amersham International, Amersham) 
using the random primer technique (Boeringer Mannheim, Lewes) and adjusted to $2 \times 10^{5} \mathrm{cpm} /$ $\mathrm{ml}$ in hybridisation buffer.

Whole eye sections of $12 \mu \mathrm{m}$ thickness were cut on a cryostat and mounted on specially prepared gelatin coated slides. Sections were fixed for 5 minutes in $4 \%$ glutaraldehyde, rinsed twice in hybridisation buffer and soaked in hybridisation buffer for 1 hour, rinsed in ethanol, and dried. The ${ }^{35} \mathrm{~S}$ labelled probe in hybridisation buffer was heated to $90^{\circ} \mathrm{C}$ for 10 minutes, cooled, and $100 \mu \mathrm{l}$ applied to each slide under a parafilm coverslip. Sections were left to hybridise in a humidified chamber at room temperature for 72 hours. After hybridisation, slides were immersed in $2 \times$ SSC until the coverslips dislodged, rinsed in $2 \times S S C$ and washed at $40^{\circ} \mathrm{C}$ for 30 minutes in $1 \times$ SSC. Slides were then rinsed briefly in distilled water, in $70 \%$ ethanol for 5 minutes, in $\mathbf{9 5 \%}$ ethanol for 5 minutes, and allowed to dry.

Control sections from each eye were fixed for 5 minutes in glutaraldehyde buffer, washed, and $100 \mu \mathrm{l}$ of RNAse A (Boehringer Mannheim) $1 \mathrm{mg} / \mathrm{ml}$ in $2 \times \mathrm{SSC}$ were applied to each slide under a parafilm coverslip and incubated at $37^{\circ} \mathrm{C}$ for 1 hour. Slides were then washed in $2 \times$ SSC and simultaneous hybridisation with each probe carried out as above.

To determine the specificity of the lymphokine probe hybridisation, each section was also hybridised with a ${ }^{35} S$ labelled probe to the P53 oncogene which was considered to be irrelevant to the EAU disease process.
AUTORADIOGRAPHY

The slides were dipped in K5 (Ilford, Mobberley) photographic emulsion diluted $1: 1$ in $0.5 \%$ glycerol, and left to expose at $4^{\circ} \mathrm{C}$ for $21-24$ days over silica gel. Slides were then developed and counterstained with haematoxylin.

\section{IMMUNOHISTOCHEMISTRY}

Sections of each eye were stained by a standard avidin-biotin-complex method (Vector, Peterborough) using primary monoclonal antibodies to pan rat T cells (OX 19, Serotec, Oxford), IL2 receptor (OX 39, Serotec), and MHC class II expression (OX 6, Serotec).

\section{Results}

EAU

Animals uniformly developed histological evidence of disease on day 12 post-induction. The histological changes were characterised of rat EAU. ${ }^{6}$ There was a marked mixed leucocyte infiltrate of the anterior and posterior segments of the eyes with patches of retinal oedema progressing to a total retinal destruction in which lymphocytes were the predominant infiltrating cell.

\section{LOCALISATION OF LYMPHOKINE MRNA}

Eyes from 24 immunised and four control (non-
Figure 1 (A) Multiple foci of positive localisation of of positive localisation of (arrows to examples) and retina $(R)$ (arrowheads to examples) at day 14 postimmunisation.

Haematoxylin counterstain, $\times 120$. (B) Adjacent section to $(A)$ pre-treated with RNAse. No localising signal with IL 4 probe.
Haematoxylin counterstain, $\times 120$.

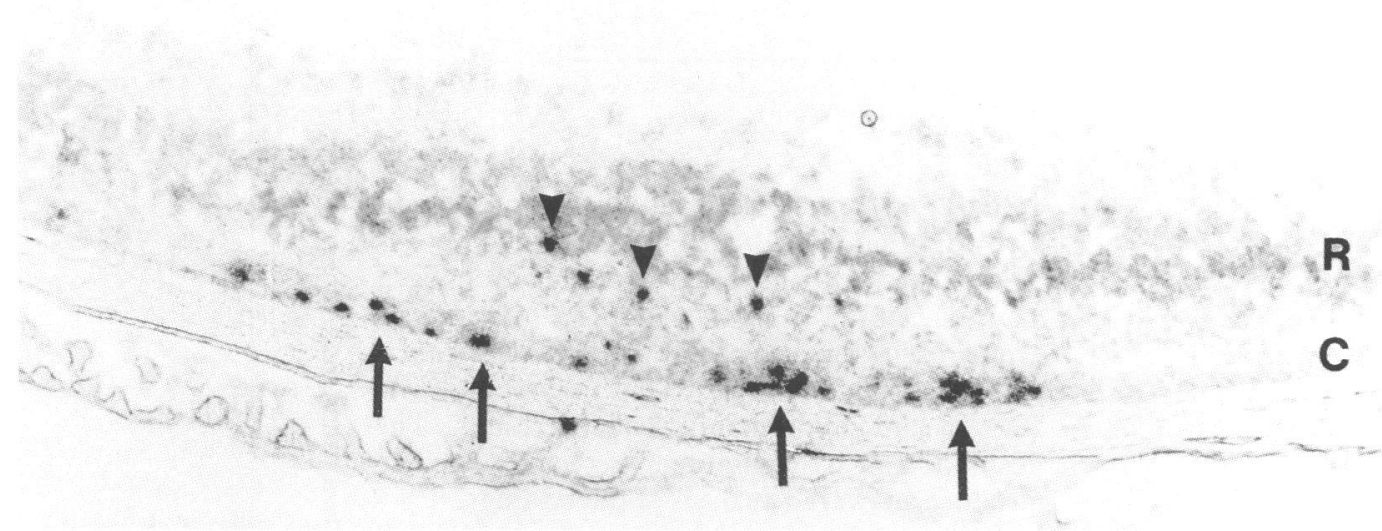

Fig 1A

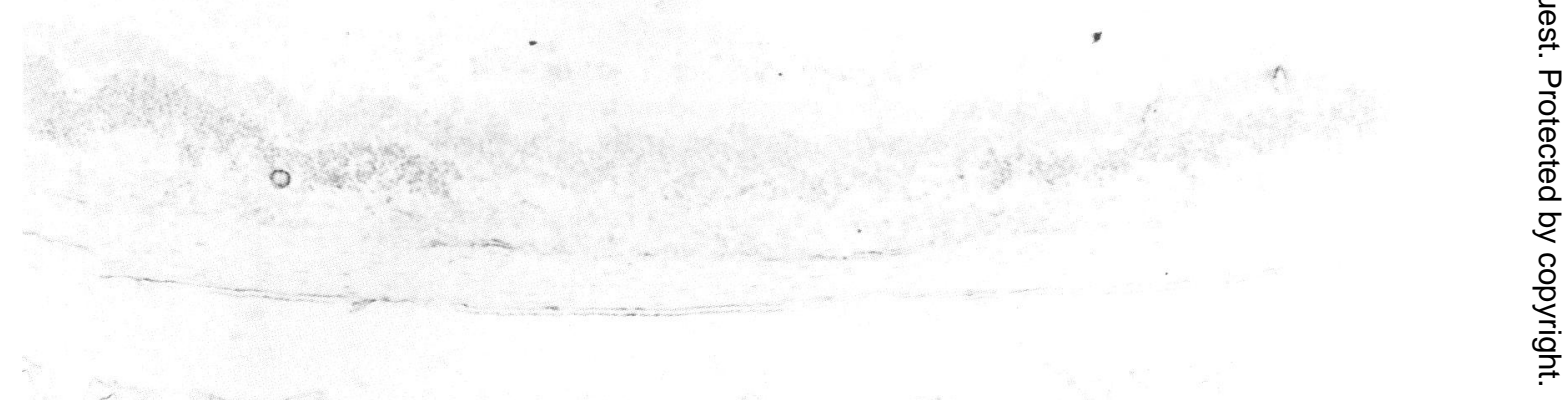


Table 1 Experimental autoimmune uveoretinitis: interferon $\gamma$ probe

\begin{tabular}{|c|c|c|c|}
\hline Disease stage & $\begin{array}{l}\text { Early } \\
\text { days } 12-13 \\
(n=16)\end{array}$ & $\begin{array}{l}\text { Intermediate } \\
\text { days } 14-17 \\
(n=28)\end{array}$ & $\begin{array}{l}\text { Late } \\
\text { day } 21 \\
(n=8)\end{array}$ \\
\hline $\begin{array}{l}\text { Uvea } \\
\text { Retina } \\
\text { Total }\end{array}$ & $\begin{array}{l}0.86(0.28) \\
1.50(0.74) \\
2.31(0.81)\end{array}$ & $\begin{array}{l}3.89(0.93) \\
0.54(0.19) \\
4.43(1.02)\end{array}$ & $\begin{array}{r}31.37(3.89) \\
0.75(0.39) \\
32.12(3.67)\end{array}$ \\
\hline
\end{tabular}

Mean positive hybridisation foci per whole eye section. $\mathrm{n}=$ sections counted $(\mathrm{SEM})$.

Table 2 Experimental autoimmune uveoretinitis: IL2 probe

\begin{tabular}{llll}
\hline & $\begin{array}{l}\text { Early } \\
\text { days 12-13 } \\
(n=12)\end{array}$ & $\begin{array}{l}\text { Intermediate } \\
\text { days 14-17 } \\
(n=15)\end{array}$ & $\begin{array}{l}\text { Late } \\
\text { day 21 } \\
(n=6)\end{array}$ \\
Disease stage & $2 \cdot 0(0 \cdot 78)$ & $11 \cdot 0(3 \cdot 11)$ & $16 \cdot 5(5 \cdot 14)$ \\
\hline Uvea & $5 \cdot 5(2 \cdot 94)$ & $3 \cdot 27(1 \cdot 04)$ & $6 \cdot 33(3 \cdot 33)$ \\
Retina & $7 \cdot 5(3 \cdot 43)$ & $14 \cdot 27(3 \cdot 51)$ & $22 \cdot 83(6 \cdot 61)$ \\
Total &
\end{tabular}

Mean positive hybridisation foci per whole eye section. $\mathrm{n}=$ sections counted (SEM).

Table 3 Experimental autoimmune uveoretinitis: lymphotoxin probe

\begin{tabular}{|c|c|c|c|}
\hline Disease stage & $\begin{array}{l}\text { Early } \\
\text { days } 12-13 \\
(n=12)\end{array}$ & $\begin{array}{l}\text { Intermediate } \\
\text { days } 14-17 \\
(n=15)\end{array}$ & $\begin{array}{l}\text { Late } \\
\text { day } 21 \\
(n=6)\end{array}$ \\
\hline $\begin{array}{l}\text { Uvea } \\
\text { Retina } \\
\text { Total }\end{array}$ & $\begin{array}{l}1.1 \quad(0.50) \\
0.92(0.54) \\
2.0(0.95)\end{array}$ & $\begin{array}{l}2.27(0.92) \\
0.2 \quad(0.14) \\
2.47(0.94)\end{array}$ & $\begin{array}{c}12 \cdot 67(4 \cdot 07) \\
8 \cdot 0(4 \cdot 61) \\
20 \cdot 67(8 \cdot 09)\end{array}$ \\
\hline
\end{tabular}

Mean positive hybridisation foci per whole eye section. $\mathrm{n}=$ sections counted (SEM).

Table 4 Experimental autoimmune uveoretinitis: IL4 probe

\begin{tabular}{llll}
\hline & $\begin{array}{l}\text { Early } \\
\text { days 12-13 } \\
(n=4)\end{array}$ & $\begin{array}{l}\text { Intermediate } \\
\text { days 14-17 } \\
(n=6)\end{array}$ & $\begin{array}{l}\text { Late } \\
\text { day 21 } \\
(n=2)\end{array}$ \\
Disease stage & $3.5(2.46)$ & $26.4(14 \cdot 19)$ & $32 \cdot 5(1.77)$ \\
Uvea & $1.0(0.61)$ & $5.4(3.58)$ & $1.0(0.71)$ \\
Retina & $4.5(3.05)$ & $31.8(17.61)$ & $33.5(2.47)$ \\
Total &
\end{tabular}

Mean positive hybridisation foci per whole eye section. $\mathrm{n}=$ sections counted $(\mathrm{SEM})$.

immunised) rats were studied by in situ hybridisation. The time points examined were as follows: days 10 and 11 , two animals from each day; days $12,13,14,17$, and 21 , four animals from each day. A total of 398 individual hybridisations were carried out to determine the pattern and reproducibility of the results. The results of all hybridisations were integrated to produce an overall analysis of the findings.

Levels of background signal (the amount of scattered dark grains in the photographic emulsion) varied on the numerous hybridisation procedures carried out but in all experiments, for all four probes, discrete collections of dark grains were identifiable over the background signal. The collections of autoradiographic signal were seen in section from eyes at day 12 postimmunisation onwards and occurred over mononuclear cells in the areas of the T lymphocyte (OX 19+) infiltrate. These foci were interpreted as positive localisation of expression of lymphokine mRNA by lymphocytes. Figure 1 provides an example of the localisation autoradiographic signal which was obtained.

To provide an estimate of the relative numbers of cells expressing mRNA for an individual lymphokine at a given time point in the disease, the number of positive foci in the retina and choroid were counted on each eye section and the mean value taken at each time point. Standard errors of these counts were calculated. These figures were grouped together as early disease (days 12 and 13 post-immunisation), established disease (days 14 and 17), and advanced disease (day 21). Tables 1-4 document the results obtained for each probe.

Figure 2 illustrates the overall comparative results for cell numbers for each probe found in the uveal tract and retina. Interferon $\gamma$ mRNA was found localised to small numbers of cells in the retina and choroid in early disease. As the destructive process progressed fewer positive cells were found in the retina and increasing numbers were seen in the choroid. Moderate numbers of cells expressing IL2 mRNA were seen in the retina throughout the course of the disease and increasing numbers of positive cells were found in choroid in late disease. Lymphotoxin mRNA was expressed by increasing numbers of cells in both the retina and choroid as the disease progressed. Cells expressing IL 4 mRNA increased initially in the retina but declined as the retinal destruction advanced whereas positive cells increased in numbers in the choroid as the disease progressed.

The numbers of positive cells for each probe were generally a small percentage (less than $10 \%$ )

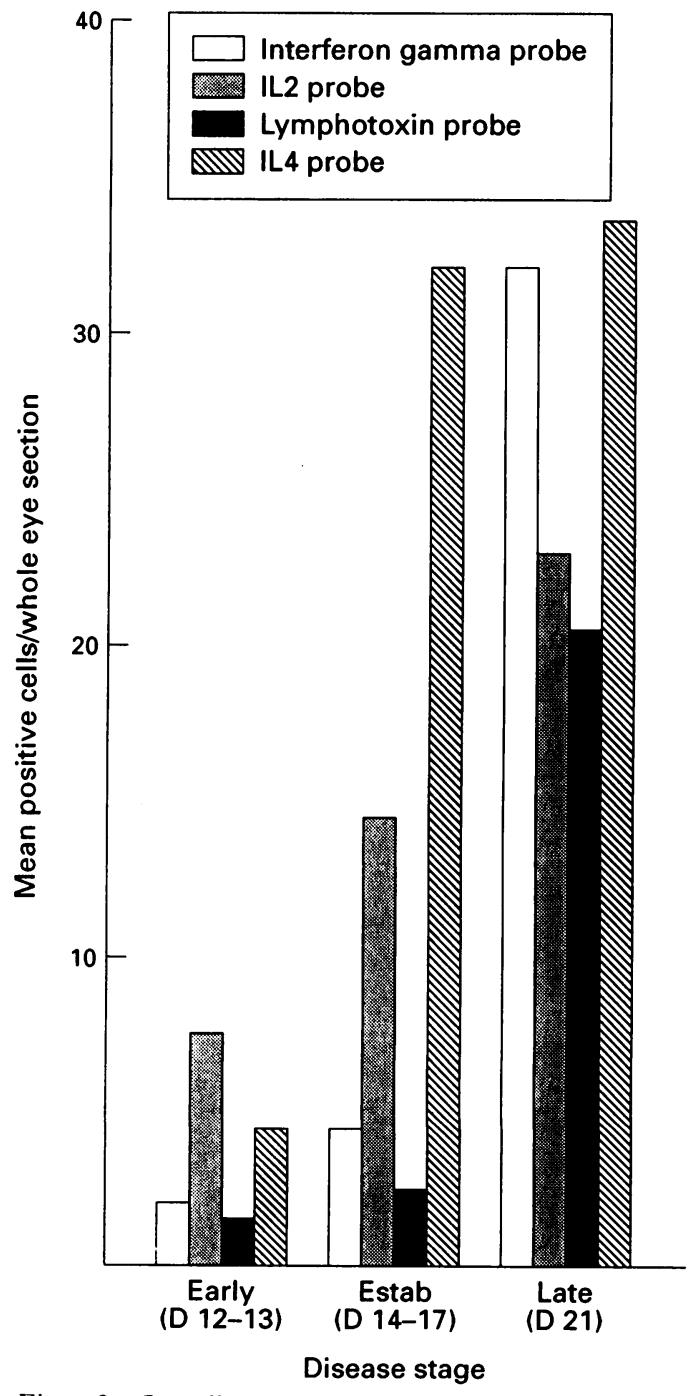

Figure 2 Overall numbers of cells expressing lymphokine $m R N A$ (mean positive cell numbers counted in the retina and uveal tract per whole eye section). 
of the total T lymphocyte number as defined by the OX19 antibody. On the frozen sections examined immunohistochemically it was not possible to make accurate cell counts of the T cell numbers because of the difficulty in defining individual cells with positive immunohistochemical stain in areas of marked accumulation of infiltrating mononuclear cells. Hence it was not feasible to calculate the percentage of cells giving positive hybridisation signal within the $\mathrm{T}$ cell population. It was, however, possible to compare the mean overall number of positive cells for each lymphokine probe within the eyes (in all areas) throughout the disease process; this is illustrated in Figure 2.

The data illustrated by Figure 2 show that increasing numbers of cells express mRNA for all four lymphokines as the disease progresses. The increase in numbers expressing IL4 mRNA is seen earliest. In general, fewer cells expressed lymphotoxin mRNA at each stage of disease process.

\section{CONTROLS}

The eyes from non-immunised animals showed no localisation of lymphokine mRNA. Pretreatment of sections with RNAase abolished all localising hybridisation signals as illustrated in Figure 1B. There was no significant hybridisation signal with the P53 probe.

\section{Discussion}

We have previously demonstrated the presence of mRNA for IFN- $\gamma$, IL2, lymphotoxin, and IL4 in areas of T lymphocyte (OX 19+) infiltration in the active stages of EAU in the Lewis rat model. ${ }^{112}$ The results presented in this paper provide an analysis of the relative numbers of cells expressing mRNA for each lymphokine throughout the disease. Increasing numbers of cells were found to express mRNA for each lymphokine as the disease progressed. The marked increase in positive cells in the late stages of the disease generally reflects an increase in cell numbers in the uveal tract since the retina is often markedly necrotic in end stage disease in EAU. The numbers of cells in the retina positive for the IFN- $\gamma$ and IL4 probes declined in late disease. Because the experimental procedure was not rigorously standardised between the probes a statistical comparison of the differences in the results for the four probes would not be valid.

In this study lymphokine mRNA was not localised to individual cells and therefore the exact nature of the cells involved has not been identified. Several lines of evidence would, however, suggest that $\mathrm{T}$ lymphocytes are expressing the mRNAs we have investigated. As documented by our previous studies ${ }^{112}$ the expression of lymphokine mRNA was found in areas of T lymphocyte (OX 19+) infiltrate as defined immunohistochemically on adjacent sections. Others have shown that $\mathrm{T}$ lymphocytes are the most common cell type in the retinal destructive lesions, ${ }^{7}$ can adoptively transfer disease, ${ }^{8}$ and are therefore likely to be producing lymphokines as part of active role in EAU. Moreover, IL2 and IFN $-\gamma$ are almost exclusively $\mathrm{T}$ cell cytokines and IL4 and lymphotoxin are common T cell products. $^{916}$

Given the above evidence for lymphokine production by infiltrating $\mathrm{T}$ cells in EAU it is worth considering the potential cellular subtypes involved. Subsets of CD4+ T lymphocytes have been defined based on their pattern of lymphokine secretion and these subsets appear to correlate with the functional properties of the activated T cells. ${ }^{916}$ Th1 cells produce IL2, IFN- $\gamma$, and LT and are thought to function as cytotoxic or inflammatory effector cells and to mediate delayed type hypersensitivity (DTH) responses. ${ }^{17} \mathrm{Th} 2$ cells produce IL4, IL5, and IL6 and are considered to act as helper cells - for example, upregulating $\mathrm{B}$ cell and antibody responses. In addition, murine $T$ cell clones have been described which have an unrestricted lymphokine secretion profile ${ }^{18-20}$; these have been termed $\mathrm{Th} 0$ and it has been proposed that they represent a precursor stage in the development of the restricted Th1 and Th2 patterns. CD4+ T cells are the predominant infiltrating cell type in the early stages of EAU. ${ }^{7}$ In relation to the Thl/ Th2 CD4+ T cell dichotomy the expression of mRNA for the lymphokines IFN- $\gamma$, IL2, lymphotoxin, and IL4 by, in general, similar numbers of cells implies the presence of a mixed infiltrate of both subsets. Alternatively, the CD4+ $\mathrm{T}$ cells could be of the Th0 subtype, not yet committed to a $\mathrm{Th} 1$ or $\mathrm{Th} 2$ lymphokine secretion pattern.

The active tissue destruction seen in the more advanced stages of EAU is characterised by a mixed infiltrate of lymphocytes and other inflammatory cells such as macrophages. It is likely that macrophages are also actively involved in local cytokine production in EAU. CD8 $+\mathrm{T}$ cells, which are present in greater numbers in the late stages of $\mathrm{EAU}^{7}$ are also probably involved in the process of cytokine production.

It has been demonstrated that the majority of infiltrating $\mathrm{T}$ lymphocytes in EAU do not appear to be $S$-antigen specific ${ }^{21}$ and it would be of interest to determine the antigen specificity of the $\mathrm{T}$ lymphocytes involved in lymphokine production in EAU.

The demonstration by in situ hybridisation of cytokine mRNA on a tissue section indicates that individual cells have been stimulated to express the cytokine gene but does not necessarily mean that they are actively producing cytokine protein. This has been demonstrated for IFN- $\gamma$ production by rat CD4 $+\mathrm{T}$ cells ${ }^{10}$ where a greater frequency of CD4+ T cells positive for IFN- $\gamma$ mRNA did not correlate with the level of secreted IFN- $\gamma$ protein. It has been shown that stimulation of peripheral blood $T$ cells resulted in expression of mRNA for IL2, IL2 receptor, and IFN- $\gamma$ which correlated well with the levels of the respective proteins observed. ${ }^{22}$ Likewise, a good concordance has been demonstrated between IL2 and IL4 mRNA and secreted lymphokine as detected by bioassay. ${ }^{23}$ Recent work, however, has shown that cellular IL2 mRNA expression is not necessarily reflected by production of bioactive IL2. ${ }^{24}$ In view of the conflicting results of these studies, experimental work demonstrating lymphokine mRNA must be interpreted with caution with regard to production of bioactive 
lymphokine. The work described in this paper does, however, illustrate that the T lymphocytes within the eye in EAU are activated to express lymphokine mRNA.

It is at present uncertain whether the lymphokine secretion patterns of rat $\mathrm{T}$ cells parallel those of human $\mathrm{T}$ cells although there appear to be basic similarities between the $\mathrm{T}$ cell systems. ${ }^{162526}$ With regard to EAU the cellular infiltrate at the destructive sites in the experimental model is analogous to that found in human disease and an understanding of the effector cells involved has potential therapeutic applications in human disease. Demonstration of in vivo production of IFN- $\gamma$, IL2, lymphotoxin, and IL4 implies that these lymphokines are potentially involved in the local pathobiology of EAU. Furthermore, the presence of these four lymphokines would allow CD4+ and CD8+ T lymphocytes and macrophages to act as effector cells in the destructive process in uveitic eyes. Further experimental work is necessary to define the biological roles of locally produced lymphokines in intraocular inflammatory disease.

This work was supported by Wellcome Trust Grant No 030412 $11.4 \mathrm{R}$

I Jakobiec FA, Marboe CC, Knowles DM, Iwamoto T Harrison W, Chang S, et al. Human sympathetic ophthalmia. An analysis of the inflammatory infiltrate by hybridoma-monoclonal antibodies, immunohistochemistry, and correlative electron microscopy. Ophthalmology 1983; 90: 76-95

2 Chan CC, Palestine AG, Kuwabara T, Nussenblatt RB. Immunopathological study of Vogt-Koyanagi-Harada synImmunopathological study of Vogt-Koyanagi-

3 Charteris DG, Lee WR. Multifocal posterior uveitis: clinical and pathological findings. Br f Ophthalmol 1990; 74: 688-93.

4 Charteris DG, Barton K, McCartney ACE, Lightman SL. CD4+ lymphocyte involvement in ocular Behçet's disease. Autoimmunity 1992; 12: 201-6.

5 Charteris DG, Champ C, Rosenthal AR, Lightman SL. Behçet's disease: activated T lymphocytes in retinal perivasculitis. Br F Ophthalmol 1992; 76: 499-501.

6 Forrester JV, Liversidge J, Dua HS, Towler H, McMenamin PG. Comparison of clinical and experimental uveitis. Curr Eye Res 1990; 9 (suppl): 75-84.

7 Chan CC, Mochizuki M, Nussenblatt RB, Palestine AG McAllister C, Gery I, et al. T-lymphocyte subsets in experimental autoimmune uveitis. Clin Immunol Immunopathol 1985; 35: 103-10.

8 Caspi RR, Roberge FG, McAllister CG, El-Saied M Kuwabara T, Gery I, et al. T cell lines mediating experimental autoimmune uveoretinitis (EAU) in the rat. F Immunol 1986; 136: 928-33.

9 Mosmann TR, Cherwinski H, Bond MW, Giedlin MA, Coffman RL. Two types of murine helper T cell clone. I. Definition according to profiles of lymphokine activities and Definition according to profiles of lymphokine acti

$10 \mathrm{McKnight}$ AJ, Barclay AN, Mason DW. Molecular cloning of rat interleukin $4 \mathrm{cDNA}$ and analysis of the cytokine repertoire of subsets of CD4+ T cells. Eur F Immunol 1991; 21 1187-94.

11 Charteris DG, Lightman SL. Interferon gamma (IFN- $\gamma$ ) production in vivo in experimental autoimmun uveoretinitis. Immunology 1992; 75: 463-7.

12 Charteris DG, Lightman SL. In vivo lymphokine production in experimental autoimmune uveoretinitis. Immunology 1993; 78: 387-92.

13 Dijkema $R$, van der Meide PH, Pouwels PH, Caspers $M$ Dubbeld $M$, Schellekens $H$. Cloning and expression of the chromosomal immune interferon gene of the rat. $E M B O \mathcal{7}$ chromosomal im

14 McKnight AJ, Mason DW, Barclay AN. Sequence of ra interleukin 2 and anomalous binding of a mouse interleukin 2 cDNA probe to rat $M H C$ class II-associated invariant chain mRNA. Immunogenetics 1989; 30: 145-7.

15 Li CB, Gray PW, Lin PF, McGrath KM, Ruddle FH, Ruddle NH. Cloning and expression of murine lymphotoxin cDNA f Immunol 1987; 138: 4496-501.

16 Mosmann TR, Coffman RL. TH1 and TH2 cells: different patterns of lymphokine secretion lead to different functional properties. Annu Rev Immunol 1989; 7: 145-73.

17 Cher DJ, Mosmann TR. Two types of murine helper T cell clone. II Delayed type hypersensitivity is mediated by Thl clone. II Delayed type hypersensitivity is
clones. F Immunol 1987; 138: 3688-94.

18 Firestein GS, Roeder WD, Laxer JA, Townsend KS, Weave $\mathrm{CT}$, Hom JT, et al. A new murine CD4+ T cell subset with an unrestricted cytokine profile. F Immunol 1993; 143: 518-25.

19 Yokohama A, Evavold B, Dunn DE, Quintans J. Production of II 2 and IFN by Th2 clones. Immunol Lett 1989; 21 : 119-26.

20 Mosmann TR, Moore KW. The role of IL-10 in crossregulation of $\mathrm{T}_{\mathrm{H}} 1$ and $\mathrm{T}_{\mathrm{H}} 2$ responses. Immunol Today 1991; 7 49-53.

21 Grabstein K, Dower S, Gillis S, Urdal D, Larsen A. Expression of interleukin 2 , interferon- $\gamma$, and the IL2 receptor by
human peripheral blood lymphocytes. F Immunol 1986; 136: human

22 Carding SR, West J, Woods A, Bottomly K. Differential activation of cytokine genes in normal CD4-bearing T cells is stimulus dependent. Eur f Immunol 1989; 19: 231-8.

23 Dallman MJ, Shiho O, Page TH, Wood KJ, Morris PJ Peripheral tolerance to alloantigen results from altered regulation of the interleukin 2 pathway. $f$ Exp Med 1991; 173: 79-87.

24 Mason D. Subsets of CD4+ T cells defined by their expression of different isoforms of the leucocyte-common antigen CD45. Biochem Soc Transactions 1992; 20: 188-90.

25 Powrie F, Mason D. Phenotypic and functional heterogeneity of CD4+ T cells. Immunol Today 1988; 9: 274-7. 